bad for infants, containing a large amount of cane sugar, which is very liable to disagree. The tin is usually left open in a close and foul air as long as it is in use, and the wilk thus absorbs germs of disease which quickly set up gastro-enteric irritation. When given in the usual way (one teaspoonful to a "bottle" of water) it is far too weak to have much nutrient value to the child, which crieo, and appears to be hungry. This is of course the s1gnal fur the administration by the nurse or mother of baked flour, oatmeal, or any other "food" which a perverted ingenuity can suggest, with disastrous consequences to the child's healtb. A curious point arises here. It has been sqid that fresh cow's milk has "anti scorbutic properties" (Dr. Cheadle). ${ }^{1}$ I do not know what are the grounds for the assertion, and I trust I shall not be held presumptuous in differing from $\mathrm{D} c$. Cheadle, yet I feel compelled to traverse the statement. If we believe in the antiscorbutic power of fresh milk, we must suppose there is something in it which is not present in condensed milk. Now, condensed milk is ordinary cow's milk sterilised, partially dried, and with a high percentage of cane (or beet) sugar added. The boiling or sterilisation cannot be at fault, for this is generally advised to be done with all milk before it is given to children. Nor can we consistently blame the cane sugar, for this is said to be no worse than milk sugar. Then agaiv, one of my cases has always had new milk, and never condensed milk, while the other developed scurvy during the time he was taking new milk, when under treatment for rickets. We must, I think, admit that the scorbutic con dition occurs independently of which kind of milk is taken, and depends more particularly on the lack of other appropriate tood.

In those cases of rickets and scurvy which have been so successfully treated I would submit that the credit is more due to the raw meat juice, which is generally prescribed with the milk, and to the potato pulp than to the freshness of the milk. It is to ba hoped that the sprear of education will have some influence on the young mothers, and lead thern to gather some idea of infant physiology, especially with regard to food. At the present time very many children are brought up on dilute milk and then given starchy foods which they are utterly unable to assimilate, causing rickets, with its concomitant troubles of diarrhcea, bronchitis, deformities $t$ hoc genus omne, of which, if the victims survive, they feel the effects throughout their whole life, causing an incalculable amount of suffering which is quite preventable and should never occur.

Uxbridge.

\section{ULCERATION OF THE CORNEA FOLLOIVING INFLUENZA.}

By CHARLES HIGGENS, F.R.C.S ENG., OPHTHALMIC SURGEON, GUY'S HOSPITAL.

So many ailments-including cases of ulceration of the cornea-have been put down, with or without reason, to the results of influenza, that $I$ feel some hesitation in pub. lishing the following. It seems, however, that the two cases were sufficiently out of the common run to warrant the supposition that influenzl, from which both patients were said to have suffered severely, had something to do with the protracted course of the disease and its intractable nature. I tried in both every kind of treatment, both local and constitutional, of which $I$ have any knowledge, but am driven to the conclusion that the chief factor in the ultimate recovery of Case 2 was time. Case 1 is still under observation.

CASE 1.-W. W — aged fifty, consulted me in November, 1890. His left eye had been inflamed for a montb, and had been treated by a medical man without improvement. He had had a severe attack of influenza in Stptember. There were much superficial ulceration of the cornea, intense ciliary congestion, iritis, and a good deal of pain. The treatment prescribed was bathing with belladonna lotion, hot fomentations frequently applied, and quinine internally.
Aug. 17th the ulceration had quite healed some weeks back, but what appeared to be a blister, which varied in size from time to time, remained on the lower third of the cornea. There was also a good deal of ciliary injection. Various applications were made to the eye, but without result. The blister was destroyed with the galvanic cantery, and the cautery was also applied around the lower third of the sclerocorneal junction. Un Aug. 24th the irritation set up by the cautery had nearly passed off. The condition of the eye had very much improved.

CASE 2.-T. B-, aged thirty-five, consulted me on Jan. 7th, 1890. He had just recovered from a severe attack of influenza; both his ey es had been inflamed eight days. There was extensive superficial corneal ulceration in both eyes, the central parts being most affected. I prescribed tonics, poppy bead fomentations, and atropine, and predicted that he would be well in from three weeks to a month. At the end of a week there was no improvement, and in spite of treatment, which included, amongst other remedies, yellow oxide ointment, eserine, boracic acid, iodoform, hydrccyanic acid, and borax, the ulceration continued without much improvement till A pril. The patient then went to the seaside, and by the middle of August the ulcers had healed, leaving extensive nebulæ On Dec. $8 \mathrm{th}, 1890$, sufficient clearing had taken place to allow the right eye to read J. 12 and the left eye J. 1 , the pupils being dilated with atropine, and convex lenses used. By February, 1891, vision had improved, but there was still much corneal opacity. Brook-street, W.

\section{de attirtor \\ OP}

\section{HOSPITAL PRACTICE, BRITISH AND FOREIGN.}

Nulla autem est alia pro certo noscendi via, nisi quamplurimas et mor. bornm et dissectionum historias, tum aliorum tum proprias collectas borum et dissectionum historias, tum aliorum tum proprias collectas habere, et inter s
lib. iv. Procenium.

\section{ST. MARY'S HOSPITAL.}

CASES OF INJURY TO THE EPIPHYSES; REMARKS.

(Under the care of Mr. EDMUND OwEN.)

IT is of interest to read the account of the after result in cases of iLjury to the epipbyses if the injury was inflicted during the period of life when their integrity is essential to the proper growth of the bones. This is especially so when the injury was one unaccompanied by wound of the soft parts or uther complication, and careful note was taken of the ertent of the damage soon after its infliction. Many instances of very considerable shortening of a limb in consequence of such injury are to be found. Of these probabl the most marked have occurred after injury to the upper epiphysis of the humerus, and as this injury is not infrequently followed by ankylosis of the shoulder-joint the diminished growth of limb which results is partly dependent on the wasting which follows on the lessened use made of it. Mr. Hutchinson ${ }^{1}$ has published a case somewhat similar to the first of these. Examples of the second are less common, for Mr. Tubby, ${ }^{2}$ in a recent paper on this subject, states that he has not been able to find a case of stunted growth of either tibia or fibula following diastasis. For the report of these cases we are indebted to Mr. T. H. R. Crowle, F.R.C S., surgical registrar.

1. Arrested Development of U Ina.-A. W-, when two years old (1872), got her hand into a chaff-machine. The blade cut off the lower epipbysis of the ulna, and, traversing the tissues along the inver side of the wrist, laid the radioearpal joint freely open. She was admitted to St. Mary's Ho:pital under the charge of $\mathrm{Mr}$. O wen; the wound benled, and nothing more was se $\in n$ of the girl until she was fifteen years old. Measurement then showed that the ulna had developed but little, and that the radins, held on the inner side by the ulna, had grown in a curve, the concavity of

1 Illustrated Medical News, November, 1888 2 THE LANCET, vol. i. 1891, p. 1254 . 